\title{
DÜBLIN
}

Technological University Dublin ARROW@TU Dublin

2008-01-01

\section{Celtic Tiger Found in Education Jungle}

\author{
Thomas Cooney \\ Technological University Dublin, thomas.cooney@tudublin.ie
}

Follow this and additional works at: https://arrow.tudublin.ie/buschmarart

Part of the Education Commons

\section{Recommended Citation}

Cooney, T. (2008) Celtic Tiger Found in Education Jungle. Education and Training (Research Note), Vol.50, no.1, pp.64-66.

This Article is brought to you for free and open access by the School of Marketing at ARROW@TU Dublin. It has been accepted for inclusion in Articles by an authorized administrator of ARROW@TU Dublin. For more information, please contact arrow.admin@tudublin.ie, aisling.coyne@tudublin.ie, gerard.connolly@tudublin.ie.

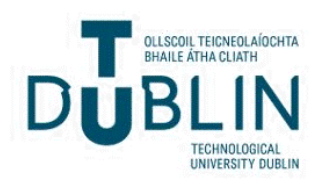




\title{
Celtic Tiger Found in Education Jungle
}

\author{
Thomas M. Cooney \\ Dublin Institute of Technology, Ireland
}

It would not cause too much debate to suggest that Ireland in the late 1950s was a depressing country. It had suffered greatly from decades of poor economic performance and the constant haemorrhaging of its population through emigration. Overcrowded classrooms and poor physical school structures meant that only 10,000 students took their Leaving Certificate in 1957 (Ferriter, 2004). Meanwhile, third-level education remained the preserve of the elite and a total of just 8,653 students were present in all of Ireland's third-level institutions by the end of the 1950s (Ferriter, 2004). The most popular solution to the ills of the time was for thousands of poorly educated people to sail to England, America, and other destinations in the hope of earning some kind of living.

But the 1960s brought significant change through a reforming Minister for Education (Patrick Hillary, 1959-65). He improved the provision of education and broadened its access. He also initiated a modified scholarship scheme for third-level education and appointed a Commission on Higher Education (Ferriter, 2004). However, arguably the most dramatic change to education policy in Ireland occurred in 1966 when the new Minister for Education (Donogh O'Malley) announced the introduction of free secondary education. Further change happened in the late 1960s with the introduction of third-level student grants which created some shift in the composition of universities with the introduction of young people from the urban middle-classes. The scheme was greatly extended in the mid-1990s with the introduction of free third-level education for all full-time students. In later years, the Enterprise Strategy Group Report (2004) highlighted the contribution that the implementation of these policies offered to Ireland's recent economic growth when it stated that:

"The fact that the labour supply was, in general, well educated made it particularly attractive to foreign direct investment. In effect, the consistent education policies of the preceding decades were bearing fruit: there was growing demand for educated human capital in all developed countries, and its ready availability in Ireland helped to attract foreign direct investment, and to promote the development of indigenous companies"

As has been evidenced, education policy has been a significant factor in the birth and maturation of Ireland's recent economic success, otherwise known as the 'Celtic Tiger'. 
While Ireland's efforts to create a well educated population that was attractive to foreign employers was highly successful, its attempts to create indigenous entrepreneurs have been less profitable until this decade. De Faoite et al (2003) noted that the role that Irish universities and institutes of technology play in the economic development of the country only became formally recognised relatively recently with the inclusion of clear economic development objectives in their statutes. The universities, while traditionally recognised for their contribution to learning and research, only took on a formal economic development role at national level during the late 1980s, while the institutes of technology (formerly regional technical colleges) saw their regional economic development role formalised in the 1992 RTC Act. Interestingly, some of the universities and institutes of technology, recognising their inherent economic development function, had already begun to establish industrial liaison and incubation units several years ahead of the formal legislation.

Increasingly young people in Ireland are being encouraged to explore entrepreneurship and enterprise development through a range of different programmes. For example, the Young Entrepreneurs Scheme targets second-level students between the ages of 12-18, Youngebiz.com targets 15-17 year olds, Shell LiveWIRE targets 16-30 year olds, and the Graduate Enterprise Scheme targets university and college graduates. In third-level institutions there are 77 undergraduate subjects/courses relating to entrepreneurship, 11 post-graduate subjects/courses, and 22 Centres for Enterprise and/or Innovation. Furthermore, the Report of the Small Business Forum (2006) stressed the need to reinforce entrepreneurship within the education system across all levels if indigenous enterprise is to flourish in future years. However, the GEM Report (2005) identified the following requirements relating to entrepreneurship education in Ireland:

- More education required at all levels on the benefits of entrepreneurship. Also educating teachers and trainers on the topic to enable them to effectively teach enterprise skills;

- Development of the entrepreneurship agenda in the education system and stronger focus on the importance of entrepreneurship as a career option;

- Identifying entrepreneurship as a career option through all levels of education primary, secondary and tertiary;

- The education system needs an overhaul: enterprise, entrepreneurship, risk taking and innovation are absent;

- Encourage creativity and innovation at all levels of the education system from primary through to third-level to help develop the entrepreneurial characteristics and traits in our young people. This will require an interdepartmental response (e.g. 
Department of Education, Department of Enterprise, Trade \& Employment) and various agencies given specific responsibility for programme delivery (e.g. CEBs, EI, etc.);

- Entrepreneurship education throughout all levels is critical if the culture is to be changed in terms of people willing to consider entrepreneurship as a career option and reducing begrudgery;

The points made by the GEM Report (2005) illustrated that the development of entrepreneurship needs to be at the forefront of education, from as early as primary education. This is required in order to foster the creative and entrepreneurial qualities of young people, and encourage a future career in entrepreneurship. The government and state agencies need to develop their support of this goal as they play a significant part in developing this process.

Whilst there is a growing consensus regarding how to develop entrepreneurial behaviours, there remains widespread concern as to how to define and monitor the outcomes of entrepreneurial education. Evidence suggests that students favour a practical approach to thinking about business ideas, writing business plans, and participating in very potential enterprise scenarios. According to Hegarty (2006) the end-result of entrepreneurship teachings should be a dynamic mix of process and action. If the requirements in entrepreneurship education, together with the initiatives and support systems discussed earlier, are taken into account and implemented, Ireland could indeed see a thriving entrepreneurial culture over the coming years. However, while much has been achieved in recent years, Ireland remains a long way from the cutting-edge of entrepreneurship education in global terms. 


\section{References}

De Faoite, D., Henry, C., Johnston, K. and Van der Sijde, P. (2003) - Education and Training for Entrepreneurs: a Consideration of Initiatives in Ireland and The Netherlands - The Education and Training Journal, Vol. 45, No. 9, pp. 430-438

Enterprise Strategy Group Report (2004) - Ahead of the Curve - Forfas, Dublin

Ferriter, D. (2004) - The Transformation of Ireland 1900-2000 - Profile Books, London

Global Entrepreneurship Monitor (2005) - The Irish Report: How Entrepreneurial is Ireland? - Forfas, Dublin

Hegarty, C. (2006) - It's Not an Exact Science: Teaching Entrepreneurship in Northern Ireland - Journal of Education and Training, Vol. 48, No. 5.

Report of the Small Business Forum (2006) - Small Business is Big Business - Forfas, Dublin

Corresponding Author: Dr Thomas M. Cooney is Director of the Institute for Minority Entrepreneurship and Research Fellow at the Dublin Institute of Technology. He can be contacted at thomas.cooney@dit.ie 